Research Article

\title{
Local Government's Tax Practices From A Cooperative Federalism Perspective
} Raj Kumar Dhungana ${ }^{a^{*}}$ Keshav K. Acharya ${ }^{b}$

a. Kathmandu University, School of Education

b. GIZ-German Development Agency

Manuscript Received: April 18, 2021

Final Revision: September 7, 2021

Accepted: September 8, 2021

\begin{abstract}
This study analyses intergovernmental revenue policies and its practices in Nepal, specifically focusing on the role of local governments (LGs) in tax administration. Both qualitative and quantitative data were used in this study that concluded LGs are gradually institutionalising internal revenue bases, and rates at the local level. The constitution 2015 has provisioned that the local governments can autonomously execute various functions including legislative, administrative, financial management, tax administration and so on. Nonetheless, imperfect experience, inadequate technical skills, limited legal and procedural grounds, and weak institutional capacity, LGs are collecting tax. Result shows tax enforcement process has been implemented with limited consultation with the taxpayers and minimal coordination with the provincial and federal government. This has created number of criticisms to the LGs about their unaccountability to the taxpaying citizens. Thus, some recommendations such as integration of technical management capacity with local, provincial, and federal level for efficient fiscal administration systems; and digitization and automation of taxation for intergovernmental cooperation have been provided for improving local economic and effective tax administration at the local level.
\end{abstract}

Keywords: federalism, fiscal governance, tax, revenue, local government, Nepal

* Corresponding author; R. K. Dhungana (rajkumar@kusoed.edu.np), K. Acharya (keshavkacharya@gmail.com), (CAuthor(s)

Published by Nepal Public Policy Review and peer-review under responsibility of Policy Research Institute Nepal.

Licensed under CREATIVE-COMMONS license CC-BY-NC 4.0

(c) (i) (8) 


\section{Introduction}

Tax is an integral source of revenue for the government as it supports to sustain the economy to a large extent (Acharya, 2017). Richard Musgrave in 1959 coined the term fiscal federalism for the first time with an illustration of tax, which is an essential part of fiscal federalism. Under fiscal federalism, firstly, the division of governmental functions and financial relations among different levels of government are defined. Secondly, the governments are qualified to:- legitimately collect taxes from different sources, allocate resources efficiently and effectively, and maintain economic stability. Thirdly, these governments take regional and local differences seriously and enforce public concerns, mainly tax rates into account (Mason, 2011). Shah (2007) illustrates that taxation is an indispensable process to build connections and interactions among the different levels of government for revenue generation, rational distribution and allocation of revenue, equitable sharing of royalties and efficient public finance management among others. In the federal system, both national and sub-national governments function within the boundary of constitutional and legislative frameworks. However, they are interconnected and interdependent and they function in partnership with different levels of the government (Acharya \& Zafarullah, 2020). Relevant legislative frameworks, effective human resource management, and commitment of the actors can create an enabling environment for the proper functioning of fiscal federalism. Furthermore, good indicators for tracking the progress and social needs, measuring work responsibilities, and expenditure arrangements are critical because effective taxation is lacking in many instances due to the inability of political and tax officials to take rational choice to go beyond political bargain (TerMinassian, 1997).

Nepal's Constitution has adopted cooperative federalism. The Constitution enshrined to have three tiers of governments: federal, state, and local based on coordination, coexistence, and cooperation, which confirms three elements of federalism: administrative, political, and fiscal federalism. The constitution has assigned tax-related responsibilities to the sub-national levels through these elements, including revenue-generation, fiscal transfers, and borrowing. Federal constitution envisions to integrate policies and powers of different levels of government, for example, sharing powers, financial resources, and cooperation among the various levels of government (Burgess, 2006). However, Nepal is continuously struggling to achieve notable results of fiscal federalism with a proper framework that could ensure the right to expenditure responsibility, and revenue assignments of three spheres of government. Looking at the theoretical perspective and international practice of fiscal federalism it seems that the source of revenue will be at the center but the responsibility for expenditure will be at the lower level. The Constitution of Nepal 2015 also provisions the main sources of revenue (namely: fiscal equalization, conditional, special, and matching grants) at the center and the responsibility of expenditure at the province and local level.

Similarly, the roles and responsibilities of the LGs have been envisaged to address the needs of the citizens and provide services to them at their doorsteps. It is necessary to increase the scope, area, and quality of services; increase the investment in services and development works; and create maximum internal revenue to address their needs (Acharya and Zafarullah, 2020). On the one hand, this process leads to transforming the LGs into autonomous bodies. On the other hand, it helps to institutionalize cooperative federalism as a major political system, which is one of the salient features of the Constitution (Chandrika and Acharya, 2020). Based

\section{Page $\mid 158$}


on this approach, both national and sub-national governments have some primary responsibilities for some policy areas. They also have exclusive and concurrent powers, which are areas of policy that are their own. Additionally, they have shared responsibilities of federal, provincial and LGs. In this context, cooperative federalism is conceptualizes two things, first, it assumes that federal, provinces, and LGs cooperate with each other in order to solve common problems; second, it highlights the principle of proximity (Chandrika \& Acharya, 2020).

The Constitution envisaged that the local governments are familiar and functional institutional structures of the government at the local level. These units not only engage in service delivery functions through institutionalization of local governance systems, but also, execute the power and functions of legislative, executive and judiciary as closest and trustworthy agents of grassroots communities (Acharya, 2018). LGs are governed according to people's choice, and local priorities that confirm a sense of good governance for the service delivery process.

Furthermore, the Constitution has introduced the concept of local revenue generation and mobilization through sources and rate of tax. On the one hand, this concept provides local autonomy to the local governments. On the other hand the local governments can generate resources through progressive tax so that LGs can address the public demands at the local level. However, motivating the citizens and properly utilizing taxes is cumbersome. Evidence shows that only about one third of local governments are able to enforce and raise taxes properly and meet the public needs and choices (Shaha, 2020). Although some LGs have conducted studies on the areas and scope of taxable and non-taxable items that allow to determine the areas and rates of taxation, it is yet to be legalised or amended through local fiscal Act. The primary reasons are that many LGs are yet to understand the roles and responsibilities that go together under fiscal federalism because of their weak institutional capacity, political and bureaucratic apathy for rules and regulations, absence of stakeholder consultation, the federal government's mindset to re-c have also rendered LGs policies and laws to be ineffective.

In general, the taxpayers expect simplified tax payment systems that are reliable, transparent, easy to handle online systems, and they also expect information regarding the amount, time and the process of paying taxes. Similarly, they expect the provision of online tax services or service delivery from their closest point such as ward offices. Using cooperative federalism perspective, this paper aims to explain how local levels of government are utilizing their mandate to collect taxes and the challenges they are facing in the process.

\section{Functioning of Tax Administration}

Fiscal federalism is a devolved function of fiscal authority or a process of granting independence and autonomy to the sub-national governments. It transfers the expenditure responsibility and assignments in generating revenue to the lower levels of governments (Shah, 2020). Many federalized countries have managed financial relations between national and sub-national units, enhanced economic growth and efficiency of public expenditures, and maintained horizontal fiscal equality and macro-economic stability under fiscal federalism framework (MartinezVazquet and McNab, 2005). Shrestha (2019) explains that such achievements are cooperative and coordination function of different tiers of the government. These functions bring substantial results in public finance management, resources allocation and resource generation and economic growth. In developing countries, many governments have prepared a variety of strategies to achieve effective and efficient fiscal federalism mainly on the allocation of 
resources, stabilization of the economy, formulation of monetary policies, taxation, regulation of customs and value added tax (VAT) (Ter-Minassian, 1997).

Nepal has constitutionally divided the power and resources not only between the federal and provinces, but also shared them with the local levels. Moreover, it has enshrined cooperation, coordination and coexistence among three levels of the government. From cooperative federalism standpoint, it is expected that the governance system will be functioning autonomously. In the process partnership among the three tiers of the government is expected to develop, whereby all partners would equally participate in the governance system, engage in maximum public welfare mechanism, and be responsible and accountable to the citizens' concerns. To institutionalize fiscal federalism, the Constitution has provisioned four areas, namely: (i) distribution of expenditure responsibilities (including to which level of government), (ii) revenue assignment (which tax and non-tax revenue to pay to which level of government), (iii) intergovernmental fiscal transfers (which grants to allocate to either state or local levels) (iv) and internal debt (Which level of government can get how much loan). It is important that the Constitution has granted the rights to all levels of governments to levy taxes as a source of internal revenue.

Among all, the local governments are considered instrumental in bringing efficacy on fiscal federalism because they are closer to the citizens. This makes the local governments responsible for a variety of service delivery. Similarly, LGs have also been collecting two types of resources. The first is various forms of tax revenues (wealth tax, house rent, house land registration fee, motor vehicle tax, land revenue, entertainment tax, advertisement tax, and business tax etc). The Second is non-tax revenues (service charge, tourism fee, and penalty and fine etc.) (GoN, $2017 \mathrm{~b}$ ) revenue. LGs are also liable to collect taxes on roads and consumption of water, electricity and public libraries, public toilets, parks, ponds, bus parks, drainages, bridges, or any other public properties.

According to global practice, tax enforcement should be based on two principles in particular: the taxpayer's ability to pay taxes and the benefits/facilities that taxpayers can receive from the government; however such enforcement practices could be beyond the constitutional spirit, for example in the case of South Africa (Fritz, 2017). In addition to that, the Constitutional provisions of two methods of fiscal transfer from federal and provincial governments to the LGs are also in practice. The first is the distribution of revenue and the second is in the form of grant. After the implementations of federalism, the local levels have received the responsibility of identifying the areas of taxation and determine the rates of taxation with the broader participation of a wide range of stakeholders (Ter-Minassian, 1997). However, in practice the local governments do not have significant tax collection power. The government of Nepal, nevertheless, has devolved the power and functions in terms of revenue assignments (Shah, 2007). Similarly, the legislative practice of federalism indicates that each level of government tries to control taxation related assignments under its own regulation and shift the liabilities to other levels (Peterson, 1995). Although the local governments are considered efficient in their allocation function, the collected funds are not used effectively and efficiently to address the needs of the citizens, specifically the needs of marginalised communities.

\subsection{Federalizing the Fiscal Authorities in Nepal}

Nepal has a long standing history of decentralisation and devolution of power from national to the sub-national levels, The first attempt of decentralization initiative in Nepal started in 
1954 through the creation of local government called Panchayat. The Panchayat governments were created at the district, municipal and village levels. The country was divided into 75 districts. In the 1980s, the Decentralization Act 1982 and Regulation 1984 were promulgated to decentralise the planning and implementation of development activities (Acharya, 2014). However, the tax collection and revenue generation at the local level was centralized. For example, the land registration was collected by the district land registration office under the central government. After restoration of democracy in 1990, the Local Self Governance Act (LSGA) 1999 and Local Self Governance Legislation 2000 were promulgated that devolved the rights and responsibilities of various types of expenditure and revenue collection responsibilities to the local levels (Acharya, 2018).

Before promulgation of the Constitution 2015, the LSGA 1999, LSGR 2000 and LSGFR 2007 defined the local revenue assignment and its operational details. The local bodies were assigned to collect house and land taxes, land revenue (Malpot), local market tax/shop tax (HaatBazzar tax), vehicle tax (registration, renewal and lump sum), entertainment tax, BahalBitauri tax based on rent, tenancy and advertisement, business tax, commercial video tax, natural resource utilization tax and other taxes like collection and savings tax (ADB, 2009). From 2001- 2002, the government piloted the full devolution of some services for example: sub-health posts, primary education, agriculture extension including livestock services, small rural infrastructure and postal services at the local levels. However, the expenditure responsibilities handed over to the local bodies has become lip service. Only a few of them were implemented due to the lack of political will and resources. Similarly, the allocation of public expenditure between regions and districts was highly influenced by political forces. Political forces influence the provision of LSGA, and the control of central authority has been continuing.

Since establishment of federalism in 2015, Nepal has been practicing the power devolution system through constitutional provision, which was limited to delegation and deconcentration mechanisms in the past (GoN, 2015). Nonetheless, post enactment of the 2015 Constitution and the completion of local elections, the practice of financial federalism and local autonomy in Nepal have moved forward intensively in which locally elected representatives and current institutional frameworks have immensely enhanced the LGs authorities in fiscal governance. In order to expedite the federalizing fiscal authorities, the Constitution has instructed to prepare number of laws such as Local Government Operation Act 2017, which defines functions of various components of local bodies; the Intergovernmental Fiscal Management Act 2017, which spells out ways to provide grants to subnational governments and distribute the proceeds generated from the use of natural resources among the three tiers of the government.

The National Natural Resource and Fiscal Commission (NNRFC) Act 2017 enables the devising a formula for the distribution of revenues and royalties among the three tiers of government in an equitable manner. The mandates of the NNRFC are expenditure responsibility, revenue authority/responsibility, intergovernmental finance transfer, internal credit rights, and the proper dissemination of royalties/revenue of the natural resources (GoN, 2017c). These provisions indicates that Nepal's fiscal federalism is moving towards cooperation, coexistence, and coordination. Which in turn focuses on revenue-raising power through taxation among the governments. Further, with the exception of their role of enriching the constitutional authorities and some other exclusive mandates, the LGs are considered 
autonomous institution closer to the people in terms of decision making and service delivery point of view.

The purpose of Intergovernmental Fiscal Management Act 2017 is to maintain relationship between three levels of government under the federalisation processes: structures, rules, and institutions (GoN, 2017a). Through this concept, the local governments are allowed to collect property, house rent, real estate registration, vehicle, land, entertainment, advertisement, business and hoarding board taxes (GoN, 2015) so that they are provided necessary funds along with the constitutional functions such as the Constitution empowered the LGs with 22 exclusive functions/rights in the Schedule 8. In order to increase local revenues the LGs have the authority to levy fees on tourism activities, vehicle parking, rental services, collection of herbs and scrap, and operation of carts, rickshaws, cable cars and boats. The Constitution of Nepal has assigned tax rights to three tiers of the government through revenue assignment. Similarly, the federal government has the right to collect custom duty, VAT, excise duty, corporate income tax, and personal income tax, the major sources of revenue. Entertainment tax, advertisement tax, vehicle tax, house and land registration fee are concurrent rights of provincial and local governments. Similarly, local governments are mandated to collect property/land tax, business tax, house rental tax, and local natural resource taxes. Based on constitutional provision, LGs have powers to choose the tax base, assess the tax base, decide the rate, collect the tax, and retain the tax proceeds (Shrestha \&Vanik, 2019).

Despite the fact that LGs are provided tax administration roles on the basis of the Constitution and laws, the grants transfer system in Nepal is yet to be scientific as it is dominated by the federal ministries on the basis of their judgment and ad-hoc analysis Devkota (2021b). Currently, fiscal transfer from federal and provincial governments has been based on development status, population, and the gap between expenditure needs and revenue potential, which is insufficient and intuitive. Subedi (2013) adds that intergovernmental fiscal transfer is yet unpredictable in Nepal. Similarly, the province and local levels are less active in widening the scope of revenue rights due to limited legislation and capacity on tax administration.

Despite having low capacity at the local level, devolving power related to tax administration at the LGs positively contributes to effectiveness of municipalities than the devolving expenditure responsibilities to municipalities through fiscal transfers (Khanal, 2016). Hence, it is positive that the Constitutional mandate of distributing revenue administration among the three tiers of the government is a step towards the right direction. However, the best results can't be reaped unless this is done for the best interest of the taxpayers and large population. Further, tax system is expected to be positively contributing to the overall human development of the population. Therefore, it is essential to assess how far the LGs are executing their revenue administration related function for the best interest of their constituencies and cooperating with other levels of governments.

Birch (1995) argues that cooperation is constructive, fruitful and ensures good services to citizens and it creates an enabling environment for flexible relationships between the national and sub-national governments in which both work together on a variety of issues and programs. In addition to defining the local governments as key agents of the fiscal decision-making process, fiscal federalism Thapa \& Sharma (2011) also establishes LGs as the responsible institutions to involve local citizens in prioritization of needs related to economic prosperity and social inclusion, and also engage them to prepare plans and projects to spend tax payers

\section{Page $\mid 162$}


money on. This normative understanding of federalism is functional when all the levels of government cooperate keeping their citizens at the centre stage and the LGs, the bottom tier of the government, has financial independence with tax authorities.

\subsection{Tax Administration at the Local Levels in Nepal}

Nepal's decentralisation efforts began by setting up the Royal Commission on Decentralisation in 1963 with bureaucratic de-concentration (Kafle, 1987). Currently, many LGs have been preparing the fiscal act proposing various tax rates based on federal laws. However, there are ample examples of legal mismatch between federal and local laws and provincial and local laws. This tendency has created an additional tax burden to the citizens on one hand while on the other hand some LGs are not initiating tax related acts and regulations as they lack capacity of tax administration, and they don't want to be unpopular among the citizens. Thus, most of the LGs are largely dependent upon the fiscal transfers being received from the federal levels. It shows that the local governments are reluctant to exercise their tax related rights and to overcome these challenges, it is important to assess how the LGs are generating local revenue, the justifications of the various tax rates, tax coverage as well as the cost-effectiveness of the tax administration at the LGs.

For the administration and management of the local revenue including taxes, the LG Operation Act 2017 has made a provision of a seven-member Revenue Advisory Program and Budget Formulation Committee (RAPBFC) chaired by the Deputy Mayor of the LGs. The Committee is mandated to formulate necessary policies, laws, review the revenue rate, source, and bases of taxation (GoN, 2017b). Through these references as well as wider consultation of the local people, LGs have prepared the plan for revenue improvement. It is essential that this committee is active, competent, and capable to have effective revenue management at the LGs. However most of the LGs give less priority to revenue administration functions due to conflict between the Mayor/chair and the deputy mayor/vice chair. The unholy relationship between Mayor/ chair and chief administrative officer is also affecting the work of the revenue administration. Generally, the RAPBFC meetings are usually held once a year. They have a number of responsibilities such as (i) Projection of the internal resources such as revenue sharing, fiscal transfer of internal debt and other incomes from Government of Nepal and provincial government, (ii) Preparation of an outline for balanced development: considering the national and provincial priorities and local needs. For example: Population - $70 \%$, Geography- $15 \%$, Human Development Index- 5 \%, Under Development Index - $10 \%$ are in use (GoN, 2017c), (iii) Finalize the total ceiling of the LGs, (iv) Determining the sectoral budget ceiling at the LG, (v) Carrying out other tasks in relation to the resources estimation and determination of budget ceiling (GoN, 2017b).

Nevertheless, the practice shows the RAPBFC is not in the position to take concrete decisions because there is no guarantee of implementation of such decisions by the LGs. Likewise, most LGs do not have a focal person to run the revenue administration competently and proficiently. Some LGs have delegated the responsibility of revenue administration to junior staff, who are regulated by the chief administrative officer. Only a limited number of LGs have prepared a Revenue Reform Action Plan (RIAP) because the capacity and willingness to implement the RIAP is rather weak (Devkota, 2021b). Due to its mandate and scope, the role of RAPBCF is critical to take high quality discussions on the local tax rates, tax base and revenue projection 
for effective planning. It is essential that the open discussion should be organised with relevant stakeholders in the LG and it is equally important that such discussions also take place among the LGs of similar nature, in close collaboration with the provincial and federal level tax administration authorities. The intergovernmental coordination in tax administration is very challenging and weak in Nepal because the provincial level government is comparatively very new in the tax administration system while federal tax administration has no or very limited mandate and capacity to collaborate and engage with provincial and local tax administration authorities. Economic Survey FY 2011 to 2018 shows that Nepal's tax revenue covers 83.84 percent of the total revenue to the government in Nepal while such sources might be changing due to newly initiated federal tax systems introduced after the establishment of new LG governments. The tax can be enforced by consideration of national economic policy, transportation of goods and services, capital and labor markets, and laws made by neighboring provinces and LGs. As for the non-tax Revenue, LGs can determine the rate of non-tax revenue based on the cost of goods and services and the cost of operation and maintenance costs (Devkota, 2021a). However, the LGs cannot collect taxes on any goods being supplied by the federal government, provincial governments and any other government-owned agencies for projects being developed under foreign aid or domestic sources itself. LGs also cannot collect taxes under any other heading that are envisioned tax-free by the federal and provincial policies. Considering the varied tax practices and confusions related to tax authorities at the LGs, the Ministry of Federal Affairs (MOFAGA) has provided guidance to the LGs related to revenue administration and tax collection rights.

Regardless of such practices, tax enforcement at the local level is a new practice. It has been found that taxes have been collected without adequate discussions with local people and stakeholders. The local governments have exercised the prevailing legal tax rights based on their own understanding of tax collection. Some have imposed taxes outside the purview of the law, while others have not started practicing it despite the possibility of taxation. When enforcing taxes to citizens' income and property, LG must be sought to regarding its effective use and sustainability, so that it can contribute to governance, development, and economic prosperity. The range of taxation can be increased, not the rate of taxation. Increasing the tax rate without study or without any base might bring forth negative consequences.

\section{Research Method}

This study is situated in the context of fiscal federalization in Nepal. In the course of this study a focus group discussion was conducted with LG Officials and the officials in the Ministry of Federal Affairs and General Administration. Likewise relevant quantitative data was collected from three municipalities. In addition, the policy documents such as the Constitution of 2015, the LG Operation Act 2017, the Intergovernmental Fiscal Transfer Act 2017 (GoN, 2017a) and several related Acts and regulations were reviewed.

The data was collected purposively from three LGs: Biratnagar Metropolitan City, Nepalganj Sub metropolitan City and Resunga Municipality. The selected LGs have represented range of Metropolitan, Sub-metropolitan and municipalities. In general, it is found that the selected LGs exercised tax related activities in a better way compared to other LGs in Nepal. Focus group discussion was held with mayors and other concerned LG officials.

During the data collection period, the authors were physically present to observe LG's capacity in service delivery After collection of the primary data, descriptive analysis was prepared, 
which included a presentation capturing relevant tables and figures. Data collected through interviews was presented and the data was supplemented with participants' quotes in the results and finding section.

\section{Results and Discussions}

This section presents various tax practices of local governments in Nepal for example occupational tax, vehicle entry tax, vehicle tax, vital registration tax, service fee and charges, land and house rental tax. LGs are collecting these taxes on the basis of constitutional mandates. While collecting these taxes, LGs are facing various issues and challenges. Some of the issues are quite technical whereas a large number of issues and ambiguities are complex and the LGs cannot address these issues without the cooperation and support of provincial and federal governments. See below the observation of a mayor who was interviewed during the course of the study. His view is a reflection of the situation at the local level:

The areas and rates of tax are determined by the executive board of local governments through their own judgement. The experience and knowledge of staff and people's representatives are basic references for tax enforcement. Finally, it is approved by the annual assembly meeting then tax is enforced on the people. But, there remain many complaints and comments at the grassroots level against taxation. Sometimes the municipality receives threats from people to go to court over local level tax decisions. We are not aware of the crux of creating a gap between LGs and people, even though we follow the rules and regulations.

Above expression shows that that there were some lapses in current practice of the municipalities to determine the scope and rate of taxation. For example, many LGs did not prepare Fiscal Act and regulations, there was lack of coordination between local communities and LGs about tax enforcement, and no scientific study was conducted for reference. Practice shows that many local level governments have determined the basis and rates of tax and nontax revenue without any legal and theoretical foundation. There are number of reasons behind such a process. First, this situation has been created due to lack of knowledge about constitutional and legal provisions related to revenue and their rights and duties at the local level. At the same time, some unpopular decisions may have been made due to lack of revenue efficiency and capacity in some of the employees working at the local level and some people are not so serious about tax assessment despite being knowledgeable. The decision seems to have been made due to difference between taxes and service charges, the relationship between taxes and services, lack of knowledge about basic principles of taxation and service charges, pride and ambition to be a local government and motivation to raise more revenue.

Second, there has been a lack of adequate interaction, discussion and consultation with experts and taxpayers to determine the base and rate of revenue. This could be the reason why people feel that their government is trying to collect taxes arbitrarily. Such a drastic step of increasing the rate $\&$ range of revenue without studying the needs and terrain of the citizens within their jurisdiction has made the local government unpopular.

Third, there is a wide variation in revenue rates between the local levels. Dissatisfaction has arisen among the citizens in the local levels because different rates of taxes are levied and also different methods of assessment of taxable property and valuation are used in the same tax base at different local levels. The possible inter-sectoral negative impact on local governance is also seen in terms of revenue base/rate determination, which is not fair. 
Finally, there is a lack of information and financial capacity. In the new environment of federalism, there is a need for public awareness on issues related to revenues including tax requirements, tax and public service relations. However, such awareness programs are not conducted at many local levels. Due to the growing trend of usage of collected revenue for current expenses rather than capital expenses a lacuna exists in the areas of public infrastructures such as library, parks, good quality schools and hospitals etc.. Likewise, and poor quality exists in the public service domain. This has created dissatisfaction towards LGs, among the citizens. In this context, economic transparency and utilization of the accumulated funds in public infrastructure building and improving quality of services at the local level are the basic expectations from citizens. next section explores major types of taxes being administered by the LGs. .

\subsection{Occupational tax}

Occupational tax is a form of progressive tax and it is levied on income or benefits from a business or a profession. Such fees are collected as regular incomes of the government. The government collects taxes from people such as businessmen, doctors, and lawyers who are licensed by the government for the income they receive from their professions. Local governments levy taxes on the basis of business and enterprise services, capital investment and economic transactions in trade within their area. It is essential to conduct extensive consultation with all local government stakeholders before enforcement of occupational taxes. Businesses are registered in concerned municipalities for the sole purpose of profit.

The local level seems to pay business tax based on the amount of investment, size and volume of profit of such registered and unregistered businesses. In order to attract businesses in their jurisdiction, the local levels focus on tax exemption. In turn, this type of action motivates taxpayers to comply with tax policies. However, in majority of cases lack of: adequate consultation, information flow, commitment of taxpayers, and the tendency of the taxpayers to collect taxes continuously instead of assessing the business transactions have created dissatisfaction among the citizens at the local level. A federal level representative expressed his view about the existing business and occupational tax collection system as follows:

There is a tendency for the local level to impose higher taxes on professions, businesses and various services haphazardly without analyzing the profits or transactions of the enterprises and businesses. This has not created enabling environment for new investors to enter, nor are the existing entrepreneurs and professionals encouraged to promote the business with enthusiasm. Its immediate impact is that businesses are increasingly fleeing to next local levels with lower tax rates and a positive business environment. This will have a negative impact on the local level in the long run. In fact, the investment climate is a prerequisite for increasing economic activity, so it must be taken seriously.

This narrative shows the tendency of setting tax rates without proper study on how tax related decisions are made at the local level affects business environment and investment climate, thereby, undermining longer term consequences of those decisions.

\subsection{Vehicle entry tax and vehicle tax}

The Clause 3(5) of intergovernmental fiscal arrangement Act 2017 requires that the tax levied by the province and LGs should not be inconsistent with the national economic policy. Moreover, no obstacles should be created in carrying of goods and services and operation of

\section{Page $\mid 166$}


capital and labor market in neighboring Pradesh (state)and local governments. Based on this principle, every vehicle owner has paid the amount including custom, VAT, fuel related tax, vehicle registration fee and renewal fee. So, charging additional burden of tax on the name of vehicle entry and vehicle tax is not justifiable. Also, this is against the norms of Article 236 of the Constitution, that is related to inter-provincial trade.

The LG or province shall not levy additional taxes or fees or charges on the goods and extended services shipped from the first LG or province. However, the study finds that there was double taxation on local products in some jurisdictions. Whereas, in some other places no tax was levied and, in yet other cases, the federal government had to tell the province and local governments to do this or that. Double taxation was found due to ambiguity in the law. Thus, an immediate action is needed to clarify such ambiguity. The vehicle tax levy goes to the provincial government, which is then distributed among the LGs within the province. Some LGs have also levied vehicle tax within their boundary which is against their legal mandate. A senior official of MoFAGA expressed his view:

The decision of the federal government, especially concerning vehicle entry tax collection, has not only been lingering by the local levels but has also been neglected. The existing laws clearly explain the issue of vehicle entry tax and even though the federal government has given instructions, this problem is still there. If the local levels are not serious about this, legal action may be taken against it. This will send a negative message to the citizens.

This verbatim presents the discrepancies between what the federal ministry expects and what has been practiced by the LGs.

\subsection{Vital registration}

Although local government operation Act 2017 provisions that the vital registration related rights and functions remain to LGs, schedule 9 of the Constitution illustrates that the vital registration related right and functions fall under the concurrent rights of federation, province and LG. To settle the dispute, recommendation has been made that the vital registration process should follow the vital registration Act 1976. This Act has already determined the fees and fines. The LGs are not mandated to charge any fee or fine to the people against the Act.

\subsection{Service fee and charges}

Some LGs have charged fees for unnerved services, while they are eligible only to charge the fee for available services based on cost. An immediate action is required to stop this kind of fee charging process. Service fees are varied in different LGs within a district or within neighboring districts. So, recommendations have been made to make consistent service fees based on service cost and values, public capacity to pay the fee and rate of neighboring districts. To end this situation, the federal government should enforce a standard guideline for uniformity.

\subsection{Land, house and rental tax}

Many LGs are unclear about land, house and rental tax as they have not enforced these taxes based on any local level laws and procedures. Thus, LGs need some form of mentoring from the federal level in terms of establishing tax structures at the local level. A model law from the 
federal government can serve as a format to institutionalize rate of taxation, classification of taxes, and also to set other standard procedures that can facilitate LG taxation procedures effectively. The mandates of land, house and rental tax Act 1967 is essentially cancelled and the authority is now designated over to the LGs. In the past, 12 percent tax was levied in which 10 percent was utilized by local bodies and 2 percent was set aside for the government of Nepal. In the new context, new analysis is obligatory and LG should consider land, house and rental tax as major sources of internal revenue. Public awareness is essential to distinguish two types of taxes, namely: property tax, and land house and rental tax. An innovative initiative regarding completion of the tax mapping has been embraced by Nijhgadh municipality . This contributed to bringing all taxpayers under tax circumference. Such best practices could be disseminated to other LG units. Sometimes, acceptance of new ideas and innovation at local level could be an uphill battle. One of the immediate service recipient of sampled municipality expressed that:

Complaints that the taxes imposed by the local government are excessively high are found at the grassroots level. Last year, I paid Rs 2,900 for the land tax, but this year, the municipality has charged Rs 10,200 in the same amount of land. I sought the reason for increasing the amount of money in similar amounts of land, the answer was that the municipality carried out the property tax.

This practice indicates that for the citizens who do not have enough income the burden of such a high tax amount for their land could be a huge financial burden. Usually, municipalities do not pay attention to the development of services and infrastructure based on priority. In addition, the federal government has also forced the LGs to raise taxes and has instructed each municipalities' that their annual internal revenue should be at least Rs. 30 million, otherwise there can be some implication to grant amount sent to them.

\subsection{Property tax}

Fiscal Act 2018 has replaced the provision of Integrated Property Tax, which was enforced by the LGs for a few years. This provision is also carried out by the Local Government Operation Act 2017 as the main revenue source of LGs. The Fiscal Act 2018 is now limited merely for property taxes. Considering the imperative of integrated property tax (IPT), the LGs have demanded to revise the Fiscal Act 2018 and enforced integrated property tax system. As mayor of Nepalganj SMC expressed, "the integrated property tax system is a progressive tax culture, which was introduced as an alternative to land revenue and real estate tax". Devekota (2021b) mentioned that the potential of property tax is significantly higher than what has been collected by the LGs in Nepal. For example, large cities like Kuala Lampur is collecting 93 per cent of the total revenue from property tax while the share of property tax in Nepal is less than 20 percent.

The integrated property tax determines the rate of taxation by assessing land revenue, value of building structure, and other assets included with house and land in an integrated manner. This tax is based on a progressive concept. In the past, local levels had been practicing this tax based on land value and assessment of house structure value. In 2018, the federal government made a financial law and removed the provision of this tax. This tax served two important functions at the local level. First the local levels were able to collect significant internal revenue. Second, they fulfilled the deficiency of resources and carried out economic, social, and infrastructural development works at the local level.

Despite the federal government's decision in 2018, some local levels have closed it down, while others have continued to fall within their jurisdiction. Similarly, some LGs of study area have

\section{Page $\mid 168$}


revised the clause 63 of the Local Government Operation Act 2017 according to their convenience and exempt to levy tax for government owned properties such as buildings, land, hospital, Guthi, non profit educational institutions, religious institutions (such as temples, mosque, churches, and monasteries), drinking water reservoirs, electric powerhouses, airports, bus parks, fun parks, and properties of the diplomatic institutions. Also, LGs have exempted the tax to heritage settlements for certain time and newly developed settlements for integrated land projects that can contribute to integrate the scattered settlements.

\subsection{Stone, boulder, sand and construction related tax}

At the local level, there is no clear legal procedure for extraction of non-renewal natural resources such as stone, boulder, sand and construction related tax. A recommendation has been made to formulate clear legal procedure for utilization and renewal of natural resources under article 235(1) of the Constitution. Current practice for contracting extraction of natural resources, mainly river-based materials and minerals, are beneficial to the contractor and entrepreneurs, but the province is bearing maximum loss in terms of natural calamities such as floods and landslides. Tax related to mining of sand and boulders is always highlighted by all tiers of governments. The 2018 financial Act, has granted the authority to local levels for levying and charging the tax, however, the authority to determine the rate of taxation was given to provincial governments. In the past, the authority had been given to the LGs.

There exists some confusions among the sub-national governments in fixing the overall rates of taxation and specifically the whereabouts regarding taxation of natural resources which serve as construction materials. These complexities have created adverse effects in revenue generation. A mayor of one of the sub-metros expressed the complexities surrounding the collection of the riverine based resources at the local level as follows:

Stones, pebbles, sand, and other riverbed materials are good income sources of local governments, which remain the most conflicting issue at the local level. Disputes have arisen between the local governments and inter-governments over the revenue generated and its jurisdiction. On the one hand, it is encouraging unauthorized exploitation of riverine resources, while on the other hand, a legal battle has been started between the District Coordination Committee and the Municipalities over the issue of exercise of rights.

Nevertheless, Stones, pebbles, sand, and other riverbed materials are considered high value resources for revenue collection. Thus, all tiers of governments have to develop coordination and follow the laws to regulate and extract the resources. A clear-cut federal law needs to be promulgated, and a strong mechanism is essential to benefit the government compared to contractors.

\subsection{Trend of Revenue Collection in Local Governments in Nepal}

The tax collection data from Biratnagar metropolitan, Nepalgunj Sub-Metropolitan and Resunga Municipalities shows that tax related revenue collection is increasing each year in general. However, the level of increment is varied among different LGs. The increment in Biratnagar metropolitan is quite significant while the growth in the relatively older municipality like Nepalgunj sub-metropolitan is gradual but slower (See chart 1). 
Raj Kumar Dhungana; Keshav K. Acharya / Nepal Public Policy Review

Table 1: Trend of Local Level Tax revenue in Nepal

\begin{tabular}{|c|c|c|c|c|c|c|c|}
\hline \multirow[t]{2}{*}{ S.N } & \multirow{2}{*}{$\begin{array}{l}\text { Name of } \\
\text { the } \\
\text { Municipality }\end{array}$} & \multicolumn{3}{|c|}{$\begin{array}{r}\text { Revenue Collection in Tax Related } \\
\text { Revenue }\end{array}$} & \multicolumn{3}{|c|}{ Revenue Collection in Non-Tax Related } \\
\hline & & $2075 / 076$ & 2076/077 & $2077 / 078$ & $2075 / 076$ & 2076/077 & $2077 / 078$ \\
\hline 1. & $\begin{array}{l}\text { Nepalganj } \\
\text { SMC }\end{array}$ & 47216142.34 & 55275967.31 & 87900000.00 & 50754838.40 & 99718631.87 & 85710000.00 \\
\hline 2. & $\begin{array}{l}\text { Biratnagar } \\
\text { Metropolitan } \\
\text { City } \\
\text { Municipality }\end{array}$ & 56195007.83 & 448065000.00 & 750254851.00 & 48338729.03 & 152250000.00 & 227180000.00 \\
\hline 3 & $\begin{array}{l}\text { Resunga } \\
\text { Municipality }\end{array}$ & 3841580.00 & 6050000.00 & 12550000.00 & 7595260.00 & 6150000.00 & 6150000.00 \\
\hline
\end{tabular}

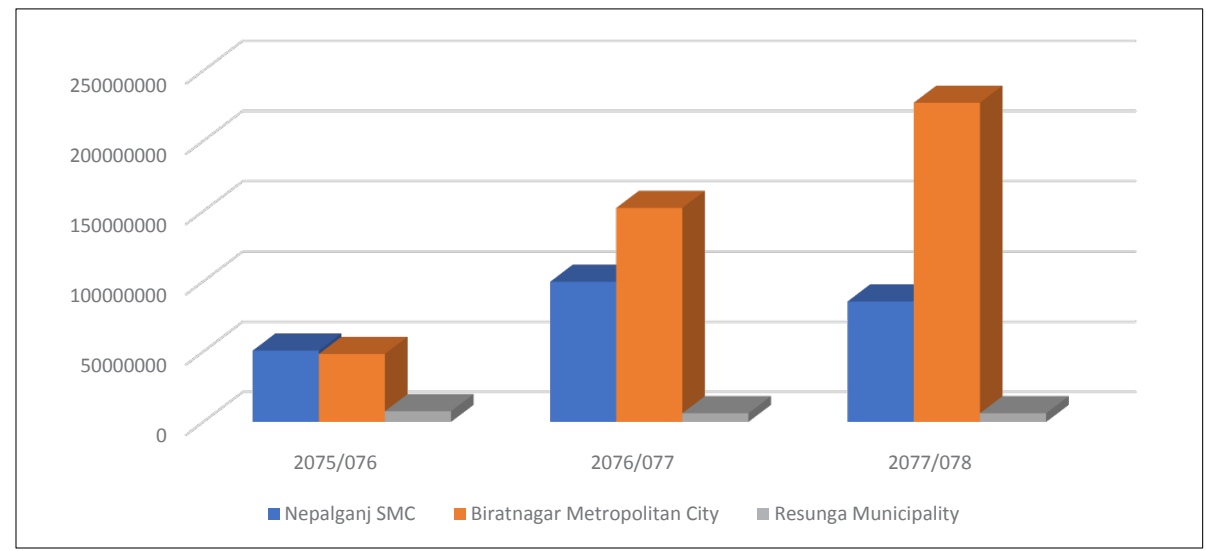

Figure 1: Revenue Collection in Tax Related Revenue

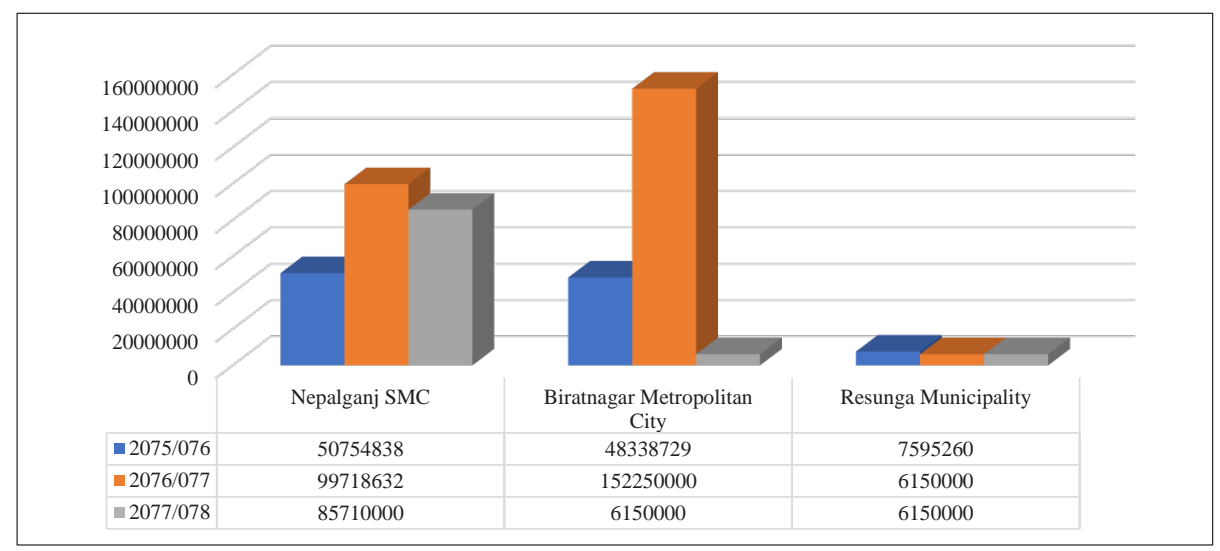

Figure 2: Revenue Collectio b n in Non-Tax Related Revenue

\section{Page $\mid 170$}


The presented data demonstrates that the LGs are actively using the tax administration authorities and collecting more taxes than before. The growth is quite significant, from 2 to 10 times in three years' time in the sampled municipalities. This data presents that LGs will be able to increase their income by improving their tax administration capacity. Though, such growth will not automatically translate to better utilization of the local revenue or improvement in the quality of lives of taxpayers. The LGs are yet to prioritize :effective and efficient service delivery to the taxpayers; increasing local economic base; and creating more jobs and reducing inequalities.

In the course of revenue collection through taxation, local governments are liable to collect taxes on roads and water consumption, electricity and public libraries or any other public properties. Likewise, the local governments can also collect taxes for various services like public toilets, parks, ponds, bus parks, drainages, bridges, among others. However, the local governments cannot collect taxes on any goods supplied by the central government, provincial governments and any other government-owned agencies for projects implemented under foreign aid or domestic sources. Local governments also cannot collect taxes under any other heading that are envisioned tax-free by the government policies. In some cases local governments have prepared their fiscal act and imposed taxes on such items, such inconsistencies have to be avoided

It is encouraging to see the growing roles, revenue sources, and capacity of revenue administration of LGs. However, the increased expenditure of the revenue in administration and non-productive or less productive sectors remains a consistent challenge. For example, the gross value added of this sector is expected to rise with the implementation of federalism and rise in administrative and security expenses of state and local levels. The contribution of this sector to GDP was 2.7 percent in fiscal year 2018/19 and grew to 3.2 percent in 2019/2020 (GoN, 2020). For effective revenue management, LGs are to consider tax-payer's capacity, rate of taxation, practices of neighbouring LGs, provincial and federal laws, as well as the interest of local stakeholders. During the 11 months period in the fiscal year 2020/2021, total revenue at the LGs was NPR 5705 million (57 Aarab, 5 Karor) of which Province 1 to Sudurpaschim Province are NPR 775, 1081, 1948, 523, 765, 224 and 386 million respectively. This presents that there is a wide gap in the amount of revenue collection by the LGs. Bagmati Province has collected about 2000 million while Karnali Province has collected only 224 million. The unequal development among different LGs can't be addressed unless the resource distribution and resource utilization are equitable and effective (Shaha, 2020).

\subsection{Legal systems and institutions}

The federal government has prepared a number of model laws related to the fiscal governance for the provincial and LGs. However, both the governments failed to fully incorporate the spirit of the model laws at their levels. These governments also fall short in coordinating with federal ministries including the Office of the Prime Minister. This is one of the reasons why rate of taxation varies within LGs, provincial governments and between provincial and LGs. To overcome the inconsistencies, the Ministry of Finance (MoF) could prepare a model law and forward it to the provincial and LGs in which these governments could apply the spirit of the MoF. In order to implement the revenue assignments illustrated in the constitutional schedules different laws, Acts, and institutions have been practiced by the federal government. 
This could have created cumbersomeness and conflict among others. To overcome these complexities, an integrated federal law is required that may help with coordination at all levels of governments.

\subsection{Tax administration capacity of the LGs}

The revenue authority granted to the local bodies in the past and LGs at present is not significantly different. In the past, both municipalities and Village Development Committees did not apply the revenue mobilisation activities, while the present LGs have widely applied revenue practices. The practice of revenue administration in all LGs have several differences due to level of understanding, weak capacity for tax enforcement, less exercise and public interaction, and inadequate preparation. Due to these types of practices citizens could fall under tax trap. Also the LGs are losing their credibility around the public. Therefore an immediate action is required to inform the taxpayers about the rate and area of the taxation.

Tax and revenue related technical support is essential for each LG unit as they have been enforcing tax, and revenues to the people without any technical foundation and research. The Constitution 2015 has granted authority to federal, province and LGs to enforce tax on the basis of approved legal procedures. However, some areas are transferred to non-state actors to enforce the tax, which is not necessarily matched to the constitutional mandate. Currently, various government projects and committees related to tourism are active to administer tax, which also remains in the provincial and LGs' jurisdiction. Tax administration is not a new function for the municipalities established before 2001 as the local self-government act LSGA (GoN, 1999). For example, in a study of taxation in Pokhara Municipality revealed that the municipal tax collection procedures are effective but the taxpayers are not paying their liabilities regularly and thus the municipality is unable to collect the minimum level of potential tax.

\subsection{Functioning of Intergovernmental Cooperation}

To bring the efficacy in utilization of LG revenues, practice on concurrent rights, and utilization and sharing of natural resources the provincial coordination council could be an effective mechanism. It is essential to link the revenue administration and taxpayers through rational mechanisms Among others, logically connecting the tax administration and taxpayers, cultivating a positive attitude towards taxation in the local people, controlling tax leakage by using professional skills and digital technology, instituting the system of awards for best taxpayers, and building scientific and progressive taxation system can help gain trust among citizens.

The question of intergovernmental cooperation is critical to ensure that there is horizontal and vertical equality. Balancing fiscal powers across provincial and local levels is a very important question. The Constitution has given fiscal, legislative, and judicial rights to local governments but the proposed legislation rolls back the share of revenue from sources like forestry, tourism, hydropower, gravel, etc. This will have a serious negative effect on the true implementation of federalism unless these forms of taxes are regulated both from climate and human justice points of views and intergovernmental cooperation is essential for this to happen.

In this process, governments mainly federal government needs to operate effectively according to Federal, province and local government Interrelation Management Act, 2077. Similarly, provincial governments need to form the provincial coordination council. Concurrently,

\section{Page $\mid 172$}


regular meetings, consultations, and discussions are enormous for the Intergovernmental Fiscal Commission. The Constitution authorizes District Coordination Committee (DCC) in coordination role. However, currently DCCs are engaged in tax related activities which needs to stop immediately. In the past, DDCs charged export tax mainly on stone, boulders, gravel, coal, brick, cement, mineral water, agro and forest-based products. Currently, the Constitution does not allow levying taxes in such a sector. Thus, the federal government instructed all provincial and LGs to stop the charge in such activities.

In addition, modernization and or digitization and automation of taxation system is another important area of intergovernmental cooperation. Digitation process is not effective unless it is integrated in the tax administration system because taxpayers pay taxes at three levels of governments. The federal, the provincial and the local tax systems should communicate with each other and data should be integrated. To maintain uniformity in fiscal administrations at LG, they have used similar types of computer software called Sub-national Treasury Regulatory Application (SuTRA). SuTRA is a financial management system which includes modules on budgeting, accounting and financial reporting to ensure transparency, accountability, efficiency and effectiveness in financial management at the local level. Tax reform is a long-term process, in the case of Nepal the major reforms implemented in 1990s have been paying off in recent years (Bolnick \& Singh, 2017). This shows that the present efforts in digitization of tax administration at the LGs will eventually pay off and will help to achieve remarkable improvements in revenue performance.

Similarly, technical management capacity is necessary to integrate the local, provincial, and federal level fiscal administration systems. Some provincial governments charge provincial development fees for industry registration and renewal. Similarly, provinces have been charging natural resources utilization tax to clinker and cement industries. Both scenarios are against Article 60 and schedule 6 of the 2015 Constitution. Thus, it is necessary to make the local level tax systems more practical, scientific, transparent and progressive. An essential action is required to make the tax administration more efficient and transparent based on its contribution to local revenue and economic flexibility. This is likely to bring more taxpayers into the tax range. To enhance overall efficiency there is a need for investment in capacity development at the LG on revenue administration sector. Additionally, federal, provincial and local levels are to timely analyze their revenue rights, capacity, and effectiveness.

In summary, the three tiers of government have been facing challenges to be effective in tax administration and such challenges are more evident at the newly established provincial and local levels. Fiscal federalization process is gradually being implemented with very little or no institutional, legislative and human resources prepared for effective implementation. Challenge remains to effectively lay a foundation of these three essential criteria in order to establish Nepal as a successful fiscal federal republic.

\section{Conclusions}

Despite poor intergovernmental cooperation, tax collection has been increased and thus the scope of local revenue potential is significantly high. Lack of uniform tax rate and taxation base across local and provincial levels creates confusions among the tax-payers and in turn reduces LGs credibility in tax administration. Local capacity of the LGs new tax administration system weakens the LGs ability to collaborate with provincial and federal levels in tax 
administration. This also threatens their independence and limits their ability to fulfill their constitutional mandate for providing effective service delivery.

The LG policies and programs are not yet prioritized to satisfy the taxpayers by investing on building local economic bases, creating more jobs, investing on health security, and reducing economic inequalities. Similarly, there are great gaps in intergovernmental cooperation in the tax administration system. Effective tax administration is impossible in federal Nepal without improved intergovernmental fiscal collaboration and improved taxpayer satisfaction regarding the services they receive from the governments and integrated taxpayer information systems.

It is yet too early to conclude that the fiscal federalisation is unable to address the unjust distribution of public wealth among the citizens and reduce inequalities in Nepal. In the current context poor intergovernmental cooperation exists, tax rate is increasing but the citizens are not at the center of tax administration, and LGs do not have enough capacity to collaborate with federal and local levels. All of these factors present a high possibility that Nepal's fiscal federalizing process is yet to empower LGs to be effective and accountable to the population that they represent. More studies are necessary to explore how far cooperative fiscal federalism has been successful in minimizing economic and social disparities in Nepal.

\section{Recommendations}

a. To develop progressive taxation system LGs need to collaborate with federal and provincial. Similarly, the LGs need to build efficient tax administration, expand tax base, and control revenue leakage to effectively mobilize internal resources and strengthen the overall tax administration system.

b. More effort is necessary to improve the methods and techniques to identify tax loop holes and fraudulent businesses within the tax administration system and promote the use of integrated digital technology.

c. DCCs are also reportedly engaged in tax related activities, which needs to stop immediately. In the past DDCs charged export tax mainly on stone, boulders, gravel, coal, brick, cement, mineral water, agro and forest-based products which is against the Constitutional provisions. Such practices should be stopped immediately.

d. Along with the tax system, the LGs should improve their service delivery such as e-Payment, mobile service, provision of tax discount if paid within a fixed period and other services to the citizens.

e. Further, with urbanization and continuous rise in assessed values of buildings, land and businesses, it is necessary to revise the rates and scope of taxation. Likewise tax administrative system needs top be improved In doing so, some large municipalities may make unexpected leaps.

f. The tax system should address the larger questions related to economic growth, just distribution of resources, reduce economic inequalities and social justice. Hence, in-depth studies should be carried out to inform policy makers for making tax policies that promote intergovernmental cooperation in an effective and just tax administration system in Nepal. 
as a redistributive tool in order to address existing gaps in education system, land rights, and other socio-economic inequalities.

h. Tax-breaks could be well formulated at all three tiers of the government to provide incentives to businesses and industries. Thus tax incentives can act as an enzyme for economic transformation.

\section{References}

Acharya, K. K. (2014). Relevance of community governance for basic service delivery in Nepal: An empirical study (Unpublished PhD dissertation). Armadale, Australia: University of New.

Acharya, K.K. (2018). Local Governance Restructuring in Nepal: From Government to Governmentality. Dhaulagiri Journal of Sociology and Anthropology, 12, 37-49.

Acharya, K. K., and Zafarullah, H. (2020). Institutionalizing Federalism in Nepal: Operationalizing Obstacles, Procrastinated Progress, Public Administration and Policy, 1727-2645.

Acharya, K. R. (2017). An Economic Analysis of Government Revenue and Expenditure in Nepal, Tribhuvan University Journal, 31(1 \& 2), 51-62.

ADB, (2009). Nepal: Critical Development Constraints, Philippines: Asian Development Bank.

Bolnick, B, and Singh, P. (2017). Domestic resource mobilization case study: Nepal leadership in public financial management II. USAID. https://pdf.usaid.gov/pdf_docs/PA00T4XQ.pdf

Birch, A. H. (1955). Federalism, Finance, and Social Legislation in Canada, Australia, and the United States. London: Oxford University Press,. 305.

Burgess, M. (2006). Comparative Federalism: Theory and practice, New York, Routledge.

Chandrika, A. and Acharya, K. K. (2020). Deconstructing Federalism through the lens of Federal Constitution of Nepal, Essays on Constitutional Law,Kathmandu, Nepal Law Society, 40, 90-117.

Devkota, K.M. (2021). BittyaSanghiyeta Ra Sthaniya Taha [Fiscal federalism and LG]. Kantipur National Daily, 11 April 2021. https:/ / ekantipur.com/opina ion/2021/04/11/161810716277294092.html

Devkota, K.M. (2021b). Subnational level finances. The Kathmandu Post, 14 August, 2021. https://kathmandupost.com/columns/2021/03/28/subnational-level-finances

Fritz, C. (2017). An appraisal of selected tax-enforcement powers of the South African Revenue Service in the South African constitutional context (Doctoral dissertation, University of Pretoria).

GoN. (1999). Local Self Governance Act 1999, Kathmandu, Law Books Management Board,Nepal.

GoN. (2015). The Constitution of Nepal. Kathmandu. Nepal Law Commission.

GoN. (2017a). Intergovernmental fiscal transfer Act, 2017,Kathmandu,Law Commission of Nepal.

GoN. (2017b). LG Operation Act 2017,Kathmandu,Law Commission of Nepal.

GoN, (2017c). National Natural Resources Fiscal Commission Act, 2017, Kathmandu, Law Commission of Nepal. 
GoN. (2020). Economic Survey 2019/20. Kathmandu: Ministry of Finance (MoF).

Kafle, M. P. (1987),.Decentralization Scheme in Nepal, In: S. B. Gurung\&P. Roy (Eds.), Planning With People: Decentralization in Nepal (11-28), Delhi, Orient Longman.

Khanal, G. (2016). Fiscal Decentralization and Municipal Performance in Nepal. Journal of Management and Development Studies, 27, 59-87.

Martinez-Vazquez, J. and McNab, R., (2005). Fiscal Decentralization, Macrostability, and Growth, Georgia, Georgia State University.

Mason, R. (2011). Federalism and the Taxing Power, California Law Review, 975-103.

Peterson, R. A., (1995). Relationship Marketing and the Consumer, Journal of the Academy of Marketing Science, 23(4), 278-281.

Shah, A., (2007). Introduction: Principles of Fiscal Federalism. In Shah, A., Kincaid, J. (Eds.), The Practice of Fiscal Federalism: Comparative Perspectives (pp. 3-42).

Shaha, S.K., (2020). SthaniyaTahakoRajshowAdhikar (LG’s Tax Rights). Prasasan, (https:// www.prasashan.com/2020/08/17/191536/ ( $7^{\text {th }}$ April 2021).

Shrestha, R., (2019). Governance and Institutional Risks and Challenges in Nepal, Manila, Asian Development Bank.

Shrestha, A. and Vanik, J. (2019). Fiscal federalism in Nepal. Kathmandu: Sammridi Foundation.

Subedi, S. (2013): Fiscal decentralization and municipal taxation in Nepal. unpublished doctoral dissertation, Faculty of Humanities and Social Science, Tribhuvan University, Kathmandu, Nepal.

Ter-Minassian, T. (1997). Fiscal federalism in theory and practice. Washington: International Monetary Fund.

Thapa and Sharma (2011). The Democratic Deficit and Federalism in Nepal: Is it a Cure or Part of the Problem?, Lex Localis 9(1):39-66 
Raj Kumar Dhungana; Keshav K. Acharya / Nepal Public Policy Review

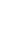

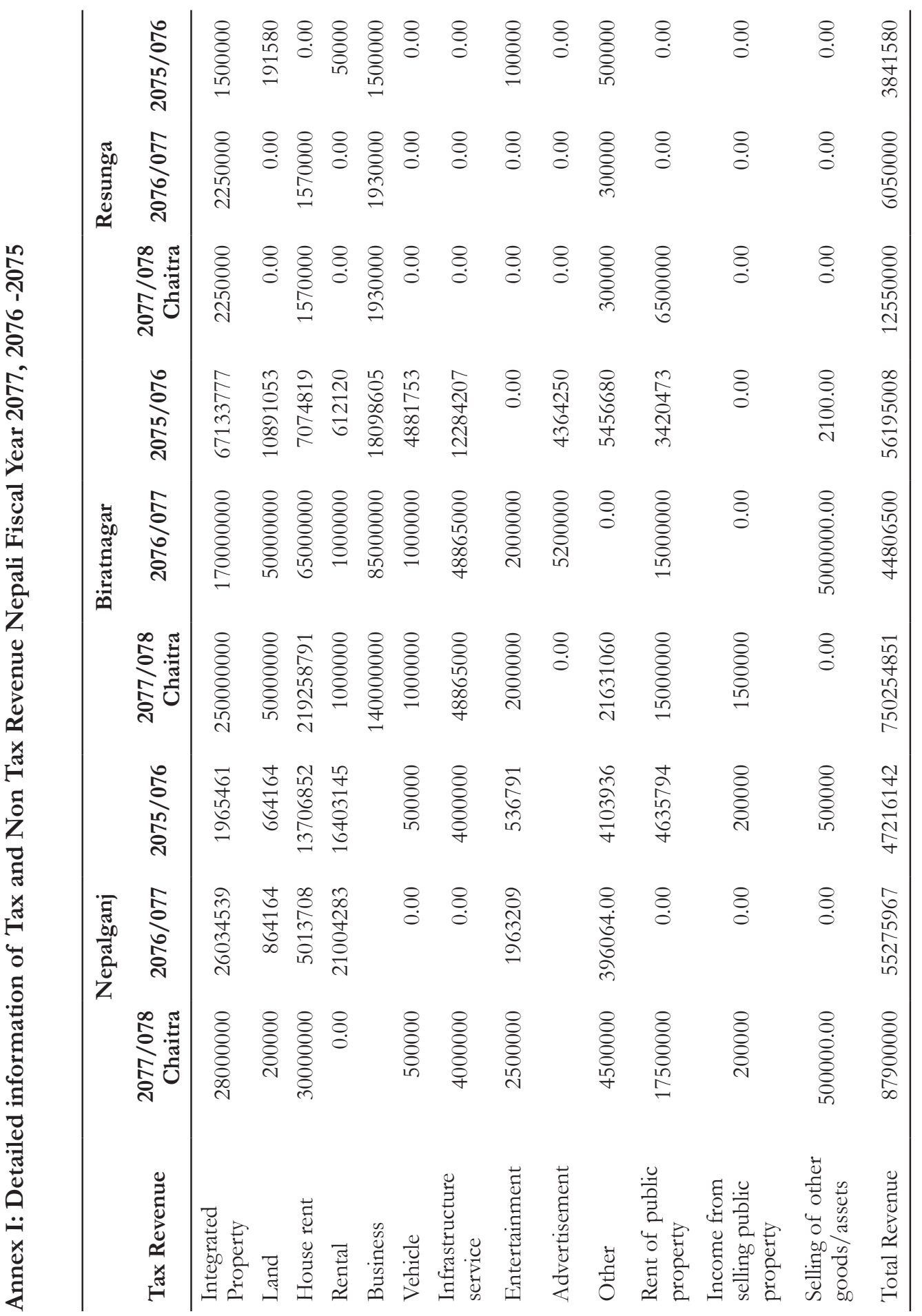

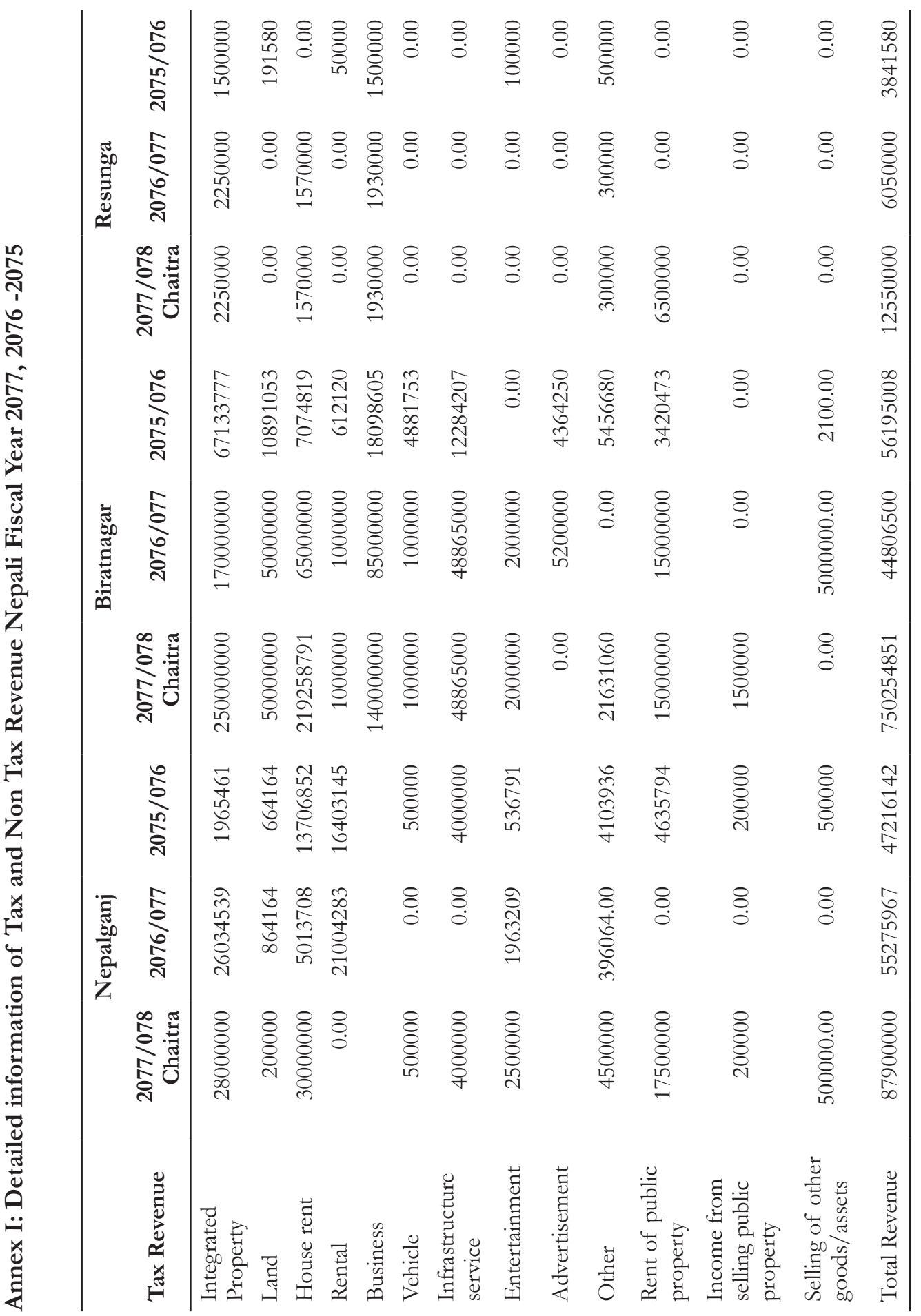

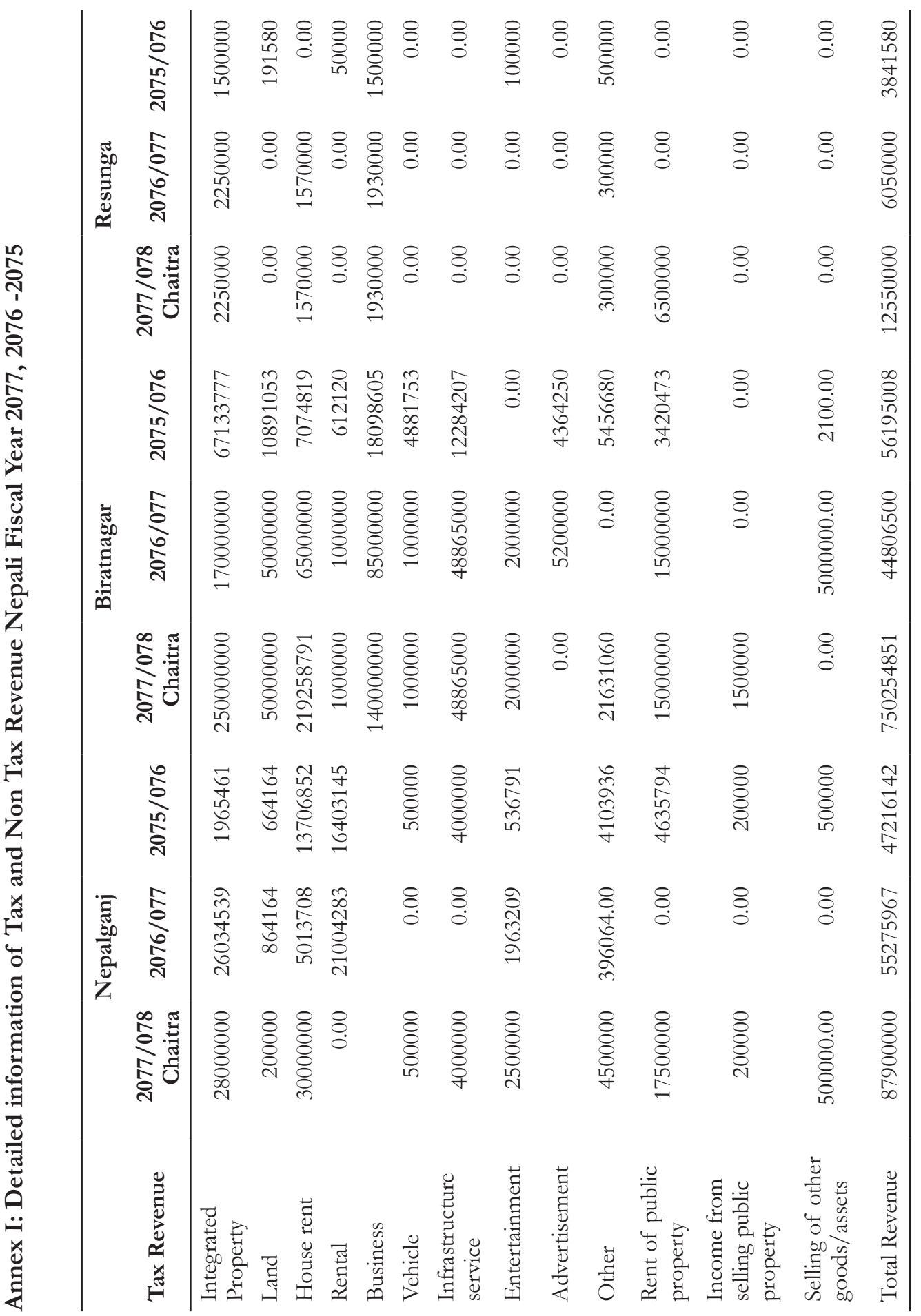

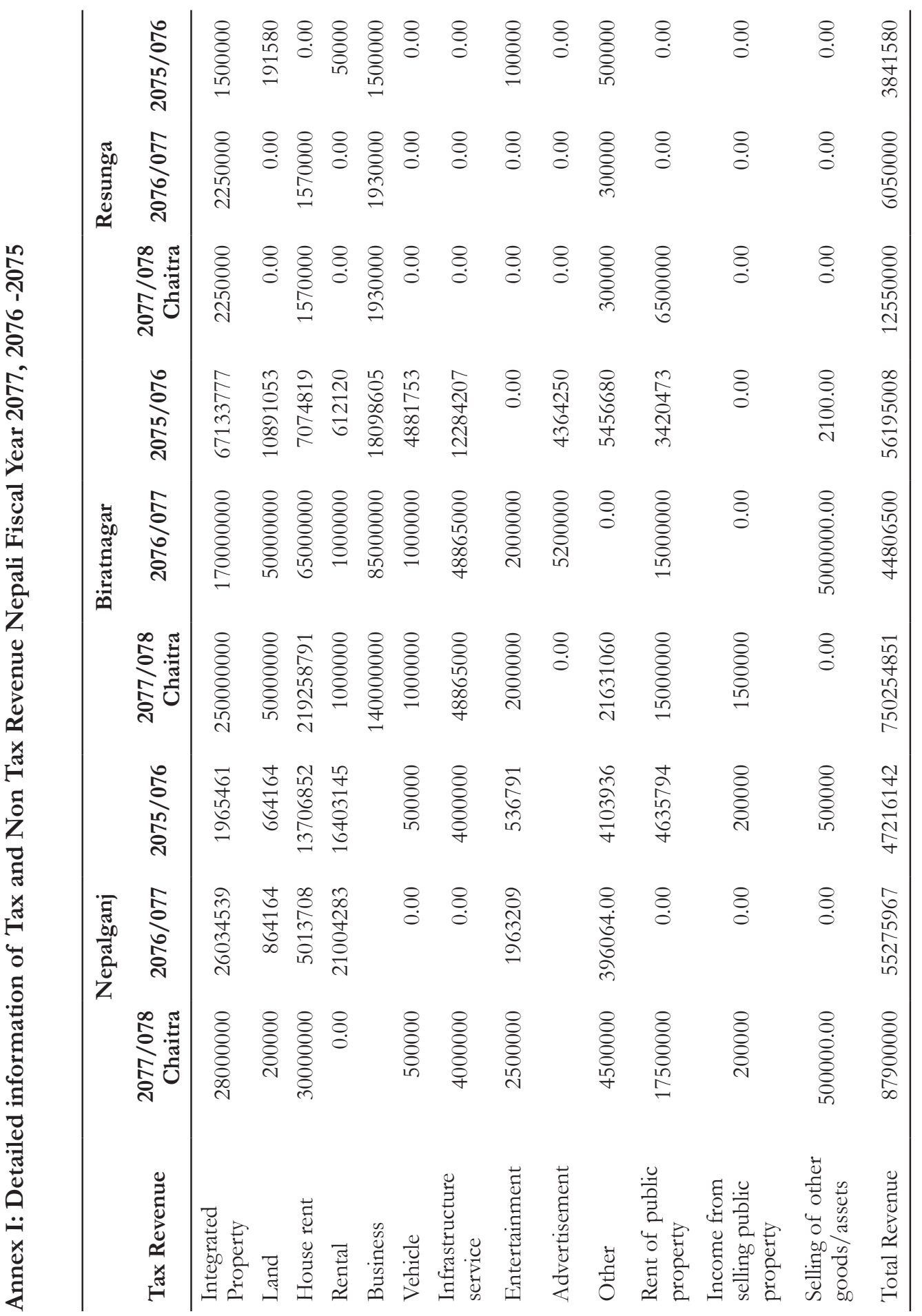




\section{Author's Bio}

\section{Raj Kumar Dhungana}

Raj Kumar Dhungana is development professional with more than 2 decades of experiences in the bilateral, multilateral, government, and civil society organizations in good governance, education, peacebuilding, capacity development, and program management. He holds $\mathrm{PhD}$ from Kathmandu University. His research interests are on governance, peace and education. He is currently working in Royal Norwegian Embassy and teaching development policy and planning as a visiting faculty member of Kathmandu University.

\section{Keshav K. Acharya}

Keshav K. Acharya is Governance Advisor of Capacity Development Support to Governance Project of GIZ Nepal. His main interest areas are federalism, local governance, public policy, capacity development, regional/urban planning, service delivery, peacebuilding, community development, and disaster management. He holds $\mathrm{PhD}$ from the University of New England, Australia and MSc from the Asian Institute of technology of Thailand. Dr. Acharya as a development expert worked in different positions of multilateral and bilateral organisations for more than 20 years. Additionally, he has written some books, articles and research papers, which are published in peer-reviewed international journals and book chapters. 